\title{
The Cultural Image of a Good Mother in Three Generations
}

\author{
SATU PERÄLÄ-LITTUNEN, Ph.D., Lecturer \\ Department of Education, University of Jyväskylä Finland
}

\begin{abstract}
In this article the image of a good Finnish mother is described and the images by daughters, sons, mothers, fathers, grandmothers and grandfathers are compared. Three members of the same family (129 families) each from a different generation were interviewed (387 persons).

The good mother loves, listens to, and controls her child. She gives advice and spends time with her child. She is patient and supportive. The good mother is an example for her child and she treats all her children equally.

When the images of the different groups were compared, it was noted that the informants could be divided into two on the basis of the images they had produced: Mothers, daughters and sons formed the "Informed" group, and fathers, grandmothers and grandfathers formed the "Traditional" group.
\end{abstract}

Keywords: image, motherhood

\section{Introduction}

Parenting is a vital activity in all cultures of the world and its quality is often under scrutiny by society, by parents and non-parents. Parenting is guided and influenced by cultural expectations, beliefs, ideas and images, and for these reasons they have been considered worth studying (Pajares 1992; Sigel 1985; Valsiner and Litvinovic 1996). In the western world especially the quality of mothering seems to be focused and the standards of good mothering have been described in the literature dealing with parenting.

The ingredients or characterisations of a good mother, i.e. the beliefs describing what a mother should be like, form an entity, an image a good mother. The image of a good mother is considered to be a reflection of the norms, especially of the expectations and obligations, prescribed for somebody occupying the role of a mother 
in the family. In this study image of a good mother is conceptualised as forming a part of the developmental context of the child and as culturally constructed phenomena. These two aspects are combined in the concept of ethnotheory formulated by Harkness and Super (1996). Parental ethnotheories are the cultural belief systems that parents hold regarding the nature of children, development, parenting, and the family (ibid.). Parental ethnotheory is not a theory in a scientific sense, in the sense that would, for instance, include rational theory formation and the testing of the premises of the theory. Instead, parental ethnotheories refer to parental common sense knowledge within a culture (Sigel and Kim 1996, 114-15).

Images are interpretations of real objects but they are not mere reflections based on perception. An interpretation is at the same time social and cognitive (Molinari and Emiliani 1990, 92) and it involves emotions. Interpretation originates in the belief systems of individuals, although interpretations, i.e. images, are culturally shared and they affect, along with other aspects of society, the functions of relevant institutions (Sigel 1996, 64, 66). Sigel (ibid. 66) also points out in discussing images of childhood, that "images reflect family and social aspirations and appropriate social behavior." Image here has a strong normative 'flavour'. The image of an ideal tells us how things should ideally be (Dunham and Bengtson 1986, 9). However, as Jahoda $(1999$, xiv) states the content of an image more often reflects the psychological needs of those describing an image than the characteristics of those described.

Images do not just exist, instead they perform functions, play a role in the way certain groups of people are treated and thought of. The functions of images used become clearer if we consider an example of more exotic images. Jahoda (1999) maintains that the images of savages were a part of the justification of the oppression of nonwestern others. In the case of good mothers the use of images in justification of, for instance, social policy decisions might not be so obvious. To see the connections between contemporary justifications and images in one's own society is harder but it is reasonable to assume that such connections take parallel forms.

Images of a good mother are entities formed from qualitative beliefs and characteristics. Similarly with beliefs, each person has an image of his or her own but the qualitative beliefs forming the image come from a cultural 'pool'. Image is here conceptualised as the description the informants of the study give when they are asked 'What is a good mother like?' 


\section{Data and analyses}

The methodological solutions of this study are those of qualitative research and the studied phenomena are understood to be socially constructed. The data collection of the study was arranged for the project "Tradition and change in parenting and parental beliefs - an intergenerational study". The project was funded by the Finnish Academy Sciences and headed by professor Sirkka Hirsjärvi and professor Leena Laurinen. Students of Education in the Open University of Jyväskylä, Finland, interviewed three members of the same family each from a different generation. During the academic year 1994-1995 it was possible for the students to take a distance education course culminating in doing the interview. The students chose the families and persons they wanted to interview and it was permissible for them to choose their own family and express first their own opinion in writing (about half of the interviewers were also informants). The students were provided with detailed instructions of how to proceed, for example, they were asked to transcribe the interviews word-by-word preserving the dialect used. In the instructions the students were also informed that their interviews would be archived, used for research purposes, and that the anonymity of the informants would be ensured.

The informants belonged to 129 families. When three members of each family were interviewed the data were elicited from 387 persons. The majority (84\%) of the interviewed persons were female ( 325 women vs. 62 men). The youngest generation was 18-35 years of age (mean 22 years), the middle aged generation was 38-64 (mean 45 years), and the oldest generation 58-89 (mean 74 years). Generation here refers to a person's position in the chain of generations (lineage generation), for instance, in the chain of a grandmother, mother and daughter. Thus the interviewees consisted of six groups: 115 grandmothers, 110 mothers and 100 daughter plus 29 sons, 19 fathers, and 14 grandfathers.

The descriptions of a good mother produced by the informants of the Finnish interview data were often lists of adjectives, for example: "A good mother is a trustworthy, warm and loving person" or characterisations of a good mother like 'a good mother is a person who cares about his family and listens to his children'. The qualitative analysis carried out here is best described as simultaneous meaning categorisation and condensation (Kvale 1996, 192-193). First, I read through the transcribed talk on a good mother. Then, I wrote down the characteristics mentioned by the informants, and as soon as it was possible, established categories so that every succeeding characterization of a good mother would not have to be given a category of its own.

After all answers had been read through, some of the categories were put together forming in the end 17 categories for a good mother (see the appendix). The categories are understood to represent beliefs, and the beliefs are the building block of images 
Next I counted the number of occurrences in each category with an aim of finding the most prevalent beliefs. Counting the frequency of each belief within the groups was considered the best way of establishing the image for each group (Huberman and Miles 1994, 252; Silverman 1993, 162). I also formed a summarising description of the image of a good mother on the bases of the frequency counts for each characterisation.

Quantifying data enabled the use of statistical tests of goodness of fit (log-likelihood ratio, $\left.\mathrm{G}^{2}\right)$ in the comparison of the images supplied by the different groups. The $\log$-likelihood ratio $\left(\mathrm{G}^{2}\right)$ was chosen instead of the more usual chi square test of goodness of fit because the log-likelihood ratio is more additive and thus more exact (Ranta, Rita and Kouki 1997, 147). The test was carried out to determine whether the images were in fact different for each group and whether it was possible to detect a pattern of similarities/differences. The tests focus on the support each group gives to a certain characterising belief, i.e. determines whether the differences in the frequencies a belief is mentioned by each group are statistically significant. As a first step, the tests were carried out taking into consideration generation, gender and the characterisation in question. The second step was to test the differences between two groups at a time and form new groups (e.g. sons and fathers in one group and grandfathers in another), and test to statistically significant differences in their images of a good mother.

\section{Findings}

\section{The good mother loves her children}

The image is approached from the angle of the beliefs it contains starting with the most often mentioned and ending with the tenth. Note, however, that we can not assume any order of importance on the bases of the frequency alone. Nevertheless, the most frequently expressed belief is the most prevalent and often the first one to come to mind. Moreover, it can be assumed that the association between the most frequently expressed beliefs and the image of a good mother is the strongest and these characterising beliefs form the core of meanings that constitute the image. 


\section{Love}

The most often mentioned characterization of a good mother in all groups of interviewees was described by words: Loving, takes care, trustworthy, helping, does not desert. The belief categories forming the image of a good mother were given 'titles'. For instance the category "Loving, takes care, trustworthy, helping, never lets the child down" was named Love. Love was talked about by a majority of informants (278 persons, $72 \%$ ). Very often the words 'love', 'loving' or 'takes care' were the first characterisations produced by the interviewees when they began to speak about 'a good mother'. The excerpts were categorised on the basis of the text in italics.

A good mother loves her child and that's how the child learns to love and one day will be able to love her/his children. (Daughter, aged 19, family 45)

"A good mother is loving. She is not angry or mean. She takes complete care of her child." (Grandmother, aged 79, family 113)

\section{Listens}

Besides 'love' the Finnish informants think that a good mother respects her child, listens to and talks to her child creating an open relationship. Qualities of this kind were put forward by $43 \%$ (168) of the persons interviewed.

A good mother respects her child's thoughts and opinions... and generally listens to her child when the child has something to say. (Daughter, aged 26, family 58)

A good mother is the kind one can trust, whom you can tell about good things and bad things. (Mother, aged 42, family 99)

\section{Control}

According to the interviewees, bringing up a child is not just 'sunshine and love'. A good mother must also be able to control and discipline her child. This was expressed by $37 \%$ (144) of the informants.

And I suppose the mother must be kind of strict when necessary, so that the child can see the limits (Mother, aged 44, family 2)

Certain rules should be taught to children at home. A child that's obedient at home is obedient at school, too. But you shouldn't use corporal punishment. (Grandmother, aged 79, family 7) 


\section{Advice}

Qualities of a good mother like giving advice and guiding the child, teaching the child (especially the importance of work and honesty) were mentioned by $29 \%$ (111) of the informants. This is how some of the informants referred to the 'teaching' aspect:

The mother is the child's first teacher who teaches what's important in life, she tells the child what's right and what's wrong... A good mother teaches her children to be honest and behave well. (Daughter, aged 20, family 57)

And yes, well, a good mother teaches the child, especially when the child is young, with her love and tenderness. Because tenderness plays an important role in the upbringing. And a good mother teaches also honesty, good manners, to take responsibility and to be responsible. (Father, aged 43, family 107)

\section{Patience}

The fifth most often mentioned characteristic of a good mother was described by words: understanding, patient (often with the help of humour), not easily upset". A little less than one quarter ( 88 persons, $23 \%$ ) of the informants talked about patience and being understanding.

In my mind at least, the most important thing is patience, and always to praise the child if the child tries to do something after all, it does not make things better if you start yelling and arguing right away, it spoils things for the whole household (Grandmother, aged 78, family 126)

Today a mot... a contemporary mother needs a lot of patience.

(Mother, aged 48, family 101)

\section{Time}

Spending time with the child, on the child's hobbies as well as arranging possibilities for the child to be active were mentioned by $19 \%$ (74) of the informants.

And then of course would try to be with her children on their hobbies and at home and would do things together with her children.

(Daughter, aged 23, family 110)

Well, it's very difficult to say, but, well, yes, a good mother can find at least some time to just be with her children. Time just for the child, so that she does not even think other matters (Mother, aged 45, family 83 ) 


\section{Support}

According to $13 \%$ (51) of the informants, supporting the child's self-esteem and trusting the child were also activities of a good mother.

In my opinion a good mother is supportive, trustworthy and guides the child towards new experiences (Daughter, aged 28, family 50)

Hmm a good mother. She is one who always trusts her child

(Grandmother, aged 84, family 20)

\section{Model}

A good mother acts also as an example for her children. This was said by $10 \%$ (39) of the informants.

A good mother is a model to her daughter. (Daughter, aged 19, family 45)

Provides an example by her way of life to her children, children use their parents as an example, don't they. You should give a thought to what kind of language you use. Children always take off their parents. (Mother, aged 42, family 73)

\section{Honesty}

According to 7\% (29) of the informants, a good mother is honest to her children, she can talk about difficult issues as they are, she apologises when there is need to do so.

And then to be honest to your children, in my opinion that's an important thing, to be honest... (Grandmother, aged 65, family 98)

... my father used to say that you must talk with children, small children. And then of course when they grow older then it's even more important to state the facts of life as they are... no stork stories (Grandmother, aged 80, family 103)

\section{Just}

Twenty-seven of the informants (7\%) said that a good mother is just and treats all her children alike, with no favourism.

... and to treat all siblings equally, so that there are no pets or favourites. (Mother, aged 43, family 59) 
... and then the parents should be fair. So that they don't discriminate against a child even though that child is difficult and then treat a better behaving child as a favourite, they should be even-handed in how they treat the difficult child. (Grandmother, aged 75, family 68)

\section{"The good mother"}

The following is a description of a good mother written on the basis of the interview. Translated quotes from the informants' speech were formed into a coherent text. The description begins with the quality most often mentioned by the informants, followed by the second quality in the order of frequency and ending with the tenth: "The duty of both a good mother and a good father is to love their child. A loving mother takes care of her child and provides the child with a safe foundation for life. A good mother shows her love by caressing her child. A mother pays attention to her child's behaviour and actions, she develops open contact with her child. The child can talk confidentially about all her/his troubles and sorrows with the mother who understands, comforts and helps when she can. A good mother lets the child manage his/her own affairs, she respects the child's thoughts and opinions.

A part of motherly love is also to control children and set the limits for them. In this way the children are given to understand that the mother cares about them. The children must not be controlled too harshly preventing them from developing a personality of their own. The children must not be shouted or yelled at, nor beaten. However, the mother's duty is to set limits and keep the control.

The mother's task is to give advice, guide and teach the child. In particular, the child must be taught the importance of work, always to tell the truth as well as to be honest and have respect for other people. The mother must also herself be always honest, explain things to her child and never lie. The mother transfers to her children 'good and important'values.

A good mother is never a violent troublemaker but she is patient, she has strength to understand her child and respond to her child with a good sense of humour and she respects the child's own preferences. The mother is interested in her child's schooling and hobbies, and most importantly spends time in activities with the child.

A good mother encourages the child to go forward and face new experiences. She has faith in her child. As the child learns by an example, the good mother sets an example to her child, especially, she acts as model of a woman for her daughter. The good mother treats all her children equally" 


\section{The "Informed" and the "Traditional"}

In the following I will present the results of the comparisons between the images of the interviewed groups. In the comparisons statistical tests of goodness of fit ( $\log$-likelihood ration, $\mathrm{G}^{2}$ ) were carried out. The results are confined to statistically significant differences only and the analysis is based on all the informants' expressed beliefs contributing to the image of a good mother. When the frequencies of expressions of the categorized qualities were compared between the six groups, statistically significant differences were found only between generations. Some gender differences emerged when comparisons were made within each generation. Finally, new groupings of the informants were tried and it was noted that the informants could in fact be divided into two new groups on the basis of similarity/differences of the images they had produced. The greatest number of statistically significant differences was between a group consisting of mothers, daughters and sons, and a group formed of fathers, grandmothers and grandfathers. The former group was named "Informed" and the latter "Traditional". The statistically significant differences between the two groups in expressing the characterizations are presented in table 1.

Table 1. Differences in beliefs characterising a good Finnish mother produced by the group 'Informed', i.e. sons, daughters and mothers and the group 'Traditional', i.e. fathers, grandmothers and grandfathers.

\begin{tabular}{lccc}
\hline Characterisation & "Informed" $\%$ & "Traditional" $\%$ & $\mathrm{G}^{2}$ \\
\hline Listening & 54 & 28 & $24.88^{* * *}$ \\
Support & 19 & 4 & $20.24^{* * *}$ \\
Control & 45 & 25 & $16.36^{* * *}$ \\
Time & 25 & 11 & $11.31^{* * *}$ \\
Responsible & 7 & 1 & $10.08^{* * *}$ \\
Patience & 27 & 65 & $6.01^{*}$ \\
Love & 76 & 7 & $5.24^{*}$ \\
Model & 13 & 7 & $3.94^{*}$ \\
Religion & 0.4 & 35 & $15.69^{* * *}$ \\
Advice & 25 & $4.82^{*}$ \\
\hline
\end{tabular}

$\mathrm{n}=387$; 'Informed' $\mathrm{n}=239$; 'Traditional' $\mathrm{n}=148$; $\mathrm{df}=1$; ' $\mathrm{p}<.05 .{ }^{* *} \mathrm{p}<.01{ }^{* * *} \mathrm{p}<.001 ; \mathrm{G}^{2}=$ loglikelihood ratio. Only statistically significant differences in frequencies are reported 
The group "Traditional" more often than the group "Informed" mentioned religious upbringing of the child and giving advice which both seem to originate from older belief systems. All other characterizations were such that the group "Informed" referred to them more often.

\section{Impact of child-rearing experts}

By naming the first group "Informed" I wish to point out that many of the characterising beliefs brought up by this group seem to be in accordance with the advice offered by present-day child care manuals and Finnish child health care centre personnel. According to Hays (1996), the most widely read manuals in the USA, Spock, Leah and Brazelton, advocate what Hays calls the ideology of intensive mothering. All these manuals have also been translated into Finnish. The child-rearing advice offered in Finland is of the 'authoritative' type (Kettunen, Krats, and Kinnunen 1996). This advice is to a large extent in accordance with the model of child-rearing offered by Spock, Leah and Brazelton.

In her dissertation Kuronen (1999) compares the advice given in Scottish and Finnish maternity and child health care and notes that Finnish mothers seem to be more willing to follow expert advice. She remarks that Finnish mothers consider using the health care services as a social right and elements of overt control have been removed from them. However, Kuronen points out that the mothers have "a strong moral obligation to use the services and follow professional advice" (ibid. 318). She also maintains that Finnish mothers, in comparison to Scottish mothers, are expected to behave in a more uniform way.

Culturally produced and expected obedience to expert advice might be one explanation for the uniformity and conformity noted by Kuronen (1999). The historical roots of the conformity of Finnish culture have been described by Ollila (1998). At the time of moulding of the Finnish identity strict conformity was required. Perhaps traces of this kind of thinking are still seen in Finnish people. Likewise, Koski (2001, 11) points out that traditionally Finnish child-rearing was based on unquestionable obedience to an authority. In the present case the authority would be invested in experts who present their advice to parents.

I am not, however, claiming that the image of a good mother of the 'Informed' is in its entirety constructed on the basis of official child-rearing advice. A more plausible explanation is that the advice adopted by Finnish experts is in fact a mixture of findings in developmental psychology and beliefs drawn from a more traditional ethnotheory of child-rearing. The close fit between what the "experts" say and what the informants say is possibly due to blending on both sides. Advice, especially when it is delivered orally in maternity and child health care centres, is a 
co-construction of the professional and the mother (Kuronen 1999). It is a mixture of scientific knowledge acquired during the training of the professional plus the professional's personal and perhaps more traditional images plus the beliefs and images the mother brings with her. It has also been noted that much of the "scientific" advice offered by experts reflects changes in cultural theories of rearing children (Harkness, Super, Keefer, Raghavan and Kipp Cambell 1996). The 'opposite', research-based knowledge becoming part of the cultural understandings also seems to be taking place. Rantamaa (2001, 57-58), in dealing with the conceptions of various age stages of life, comments, that conceptions of different developmental stages based on developmental psychological research have become part of the everyday understanding of what is normal. Moreover, mothers listen closely to the expert advice because it is especially directed at them and form their image of the ideal mother in accordance with it (Beck and Beck-Gernsheim 1995; Burman 1994; Hays 1996).

\section{Mothers and their children}

Mothers are often seen as reproducers of the culture and transmitters of the prevailing belief systems because generally they have born and continue to bear most of the responsibility for bringing up children (Phoenix and Woollett 1991, 17). This can lead to a close relationship between mothers and their children. For instance, Hosley and Montemayor (1997) concluded that the mother's impact on the adolescent is greater than that of the father. The relationship with their mothers reported by the adolescents emphasised closeness, self-disclosure, and affection (ibid. 174).

Some of the student interviewers in the present data reflected on the relationship with their mother. The interviewer of family 59 wrote:

The daughter and the mother were easily able to talk about upbringing. Probably because these issues are familiar to a modern person. Earlier the children just came along and no attention was paid to their upbringing. Although the parents had certain child-rearing principles they were not conscious of them. Even the word "upbringing" was unfamiliar.

The interviewer above is in a way presenting the mother and the daughter as 'Informed'. They were able to discuss child-rearing, they were familiar with the modern discourse.

It is possible that the similarity between the images produced by mothers and their children is a result of the closeness of their relationship which in turn is the result of the image of a good mother that the mothers have, i.e. that a good mother is one who 
loves her children, listens to them, spends time with them etc. The psychological research literature talks about 'bonding' and 'attachment'. A close relationship makes transfer of ideas and images easier. For instance, a good mother-child relationship has been noted to facilitate the transmission of moral values (Taris and Semin 1997). In another study Korhonen (1994) noted that when the mothers in her study described their mothers in positive terms, the mothering of these two generations was quite similar. Moreover, it seems likely that the nature of the ideal relationship between a mother and her children has changed with "bonding" receiving even stronger emphasis than before. For example, spending time on the child's hobbies together with the child is something that would not have occurred to the generation of Finnish grandmothers when they were mothers (Aukia 1984, 165; Korkiakangas 1996, 351). In her study Holmila $(2000,42,51,109)$ reports how the mothers in a small rural community played a role in establishing the continuity of their families by influencing, for instance, the occupational choice of their children. They were also educators of their children and even their husbands on matters like health, diet, and hygiene (ibid. 51).

One more factor explaining the similarity in the images of the youngest generation and their mothers as well as within the youngest generation is that experience as a father or mother has not affected their ideals. The majority of the youngest generation (mean age $=22$ ) have not yet formed an image of their own, instead they retain that of their mothers. They have not yet redefined themselves as parents nor tried to fulfil the requirements of their image of the ideal mother in reality. The shift in thinking that takes place as one enters parenthood has not yet occurred (Harkness, Super and Keefer 1992, 164).

\section{Discussion}

Potential transfer of beliefs and images from one generation to another seems to be at its strongest between mothers and their children. However, we can not be sure that the direction of transfer is from mothers to their children. It is possible that the similarity of these images is the result of expert advice delivered via child health care centres and mass media adopted by both mothers and children or, indeed, that children inform their mothers. These questions remain unsolved and require further study.

The transmission of parental childrearing ideas, images and beliefs is likely to be affected by the nature of these beliefs (Goodnow 1992, 295). Some beliefs may be transmitted more easily, like the belief in corporal punishment (Kemppainen 2001; Simons, Whitbeck, Conger and Wu 1991). Others, less visible beliefs, for instance mother's ideas about work identity in the study by Moen, Erickson and DempsterMcClain (1997), are not transmitted that easily. It is unlikely that the present informants had explicitly discussed their image of a good parent or even stated aloud 
what they thought on the topic before they were explicitly asked to do so. However, mothers' views might have been concluded from their behaviour.

From the point of view of the parents, providing a description of an image of good mother and its possible sources renders hidden normative expectations more visible, enabling consideration of their worth and thus possibly offering assistance and understanding to parents. Parental beliefs and images can also provide parents a standard against which they can judge their 'success' as parents and against which they can decide which aspects of parenting are important for them (McGillicuddyDeLisi and Sigel 1995, 333; Pleck and Pleck 1997, 35).

A study of this kind obviously gives rise to thoughts about how far ideas and actions match each other, whether Finnish mother are actually expected to act like the good mother the informants have described. Like LaRossa $(1997,11)$ we consider the link between the culture of parenthood and the conduct of parenthood, and like LaRossa we must similarly conclude that the relationship between thought and deed is very complicated. Even if the parents do not act according to these ideals, it is important to know what these ideals are, as parents use them as a guide in parenting and as a basis for evaluating others and themselves (Pleck and Pleck 1997, 35). Moreover, it is clear that, like other 'conceptions', images shape society's response to a phenomenon (Chafel 1997).

\section{References}

Aukia, M. 1984. Perinteisestä kotikasvatuksesta Suomen maaseudulla [Traditional childrearing in the Finnish countryside]. In: Varhaiskasvatustutkimus Suomessa, edited by M. Ojala, pp. 163-81. Lastensuojelun Keskusliiton Julkaisu 71. Helsinki.

Beck, U. and E. Beck-Gernsheim. 1995. The normal chaos of love. (First published in German Das ganz normale Chaos der Liebe. 1990. Frankfurt am Main: Suhrkamp Verlag, Cambridge: Polity Press.

Burman, E. 1994. Deconstructing developmental psychology. London: Routledge.

Chafel, J. A. 1997. Societal images of poverty, child and adult beliefs. Youth and Society [online].Vol 28 No 4 [cited 28.12.1998]. Available from: < http: www.epnet.com/ehost/ Finland/login.html>.

Dunham, C. and V. L. Bengtson. 1986. Conceptual and theoretical perspectives on generational relations. In: Life-span developmental psychology. Intergenerational relations, edited by N. Datan, A. L. Greene and H. W. Reese, pp. 1-27. Hillsdale, N. J: Erlbaum.

Goodnow, J. J. 1992. Parents' ideas, children's ideas: correspondence and divergence. In: Parental belief systems: The psychological consequences for children, edited by A. V. McGillicuddy-DeLisi and J. J. Goodnow, pp. 293-317. Hillsdale: Erlbaum.

Harkness, S. and C.M. Super. 1996. Introduction. In Parents' cultural belief systems. Their origins, expressions, and consequences, edited by S. Harkness and C. M. Super, pp. 1-26. New York: Guilford Press. 
Harkness, S., C. M. Super, and C. H. Keefer. 1992. Learning to be an American parent: how cultural models gain directive force. In: Human motives and cultural models, edited by R. G. D'Andrade and C. Strauss, pp. 163-78. New York: Cambridge University Press.

Harkness, S., C. M. Super, C. H. Keefer, C. S. Raghavan, and E. Kipp Cambell. 1996. Ask the doctor. The negotiation of cultural models in American parent-pediatrican discourse. In: Parents' cultural belief systems. Their origin, expressions, and consequences, edited by S. Harkness and C. M. Super, pp. 289-310. New York: Guilford Press.

Hays, S. 1996. The cultural contradictions of motherhood. New Haven: Yale University Press.

Hochschild, A. Russell 1997. Time bind: When work becomes home and home becomes work. New York: Metropolitan.

Holmila, M. 2000. Social bond in rural life. Regulating the dangerous. STAKES, Research Report 113. Helsinki.

Hosley, C. A. and R. Montemayor. 1997. Fathers and adolescents. In: The role of the father in child development, 3rd edition, edited by M. E. Lamb, pp. 162-78. New York: John Wiley and Sons.

Huberman, M. A. and M. B. Miles. 1994. Data management and analysis methods. In: Handbook in qualitative research, edited by N. K. Denzin and Y. S. Lincoln, pp. 428-44. Thousand Oaks, CA: Sage.

Jahoda, G. 1999. Images of savages. Ancient roots of modern prejudice in Western culture. London: Routledge.

Kvale, S. 1996. InterViews. An introduction to qualitative research interviewing. London: Sage.

Kemppainen, J. 2001. Kotikasvatus kolmessa sukupolvessa. [Child-rearing in three generations] University of Jyväskylä. Jyväskylä Studies in Education, Psychology and Social Research 190.

Kettunen, N., S. Krats, and U. Kinnunen. 1996. Parisuhde ja lasten kasvattaminen [Parents' relationship and child-rearing] In: Lapsesta aikuiseksi [From a child to a grown-up], edited by L. Pulkkinen, pp. 74-89. Jyväskylä: Atena.

Koski, L. 2001. Hyvän lapsen ja kasvattamisen ideaalit. Tutkimus aapisten ja lukukirjojen moraalisen kosmologian muutoksista itsenäisyyden aikana. [The ideal of the good child and conception of ideal child rearing - a study of changes in the moral cosmology of ABC books and elementary readers in Finland.] Research in Educational Sciences 6. Finnish Educational Research Association.

Korhonen, M. 1994 Keski-ikäisten naisten lapsuuskokemukset ja oma vanhemmuus. [The childhood experiences of middle aged women and their own parenthood]. University of Joensuu. Psychological reports 15.

Korkiakangas, P. 1996. Muistoista rakentuva lapsuus. Agraarinen perintö lapsuuden työnteon ja leikkien muistelussa. Kansatieteellinen arkisto 42. [The childhood of memory. The agrarian ethos in the recollection of childhood work and play]. Helsinki: Suomen Muisnaismuistoyhdistys.

Kuronen, M. 1999. The social organisation of motherhood - advice giving in maternity and child health care in Scotland and Finland. Doctoral dissertation. University of Stirling, January 1999.

LaRossa, R. 1997. The modernization of fatherhood. A social and political history. Chicago: The University of Chicago press.

McGillicuddy-DeLisi, A. V. and I. E. Sigel. 1995. Parental beliefs. In: Handbook of Parenting. Vol. 3 Status and Social Conditions of Parenting, edited by M. H. Bornstein, pp. 333-58. Mahwah, NJ: Erlbaum.

Moen, P., M. A. Erickson, and D. Dempster-McClain. 1997. Their mother's daughters? The 
intergenerational transmission of gender attitudes in a world of changing roles. Journal of Marriage and the Family 59:281-93.

Molinari, L. and F. Emiliani. 1990. What is in an image? The structure of mothers' images of the child and their influence on conversational styles. In: Social representations and the development of knowledge, edited by G. Duveen and B. Lloyd, pp. 91-106. Cambridge: Cambridge University Press.

Ollila, A, 1998. Perspectives to Finnish identity. Scandinavian Journal of History 23:12738.

Pajares, M. F. 1992. Teachers' beliefs and educational research: Cleaning up a messy construct. Review of Educational Research 62(3):307-32.

Phoenix, A. and A. Woollett. 1991. Motherhood: Social construction, politics and psychology. In: Motherhood. Meanings, Practices and Ideologies, edited by A. Phoenix, A. Woollett and E. Lloyd, pp. 13-27. London: Sage.

Pleck, E. H. and J. H. Pleck. 1997. Fatherhood ideals in the United States: historical dimension. In: The role of the father in child development. 3rd edition, edited by M. E. Lamb, pp. 33-48. New York: Wiley.

Ranta, E., Rita, H. and J. Kouki. 1997. Biometria. Tilastotiedettä ekologeille. [Biometry. Statistics for ecologists] (6th edition.) Helsinki: Yliopistopaino.

Rantamaa, P. 2001. Ikä ja sen merkitykset [Age and its meanings]. In: Lapsuudesta vanhuuteen. Iän sosiologiaa [ Form childhood to old age. The sociology of age], edited by A. Sankari and J. Jyrkämä, pp. 49-95. Tampere: Vastapaino.

Sigel, I. E. 1985. A conceptual analysis of beliefs. In: Parental belief systems: The psychological consequences for children, edited by I. E. Sigel, pp. 345-71. Hillsdale, NJ: Erlbaum.

Sigel, I. E. 1996. Integrative summary. In: Images of childhood, edited by C. P. Hwang, M. E. Lamb, and I. E. Sigel, pp. 63-74. Hillsdale, NJ: Erlbaum.

Sigel. I.E. and M-I. Kim. 1996. The answer depends on the question. In: Parents' cultural belief systems. Their origins, expressions, and consequences, edited by S. Harkness and C. M. Super, pp.83-122. New York: Guilford Press.

Silverman, D. 1993. Interpreting qualitative data. Methods for analysing talk, text and interaction. London: Sage.

Simons, R. L., L. B. Whitbeck, R. D. Conger and C. Wu. 1991. Intergenerational transmission of harsh parenting. Developmental Psychology 27(1):159-71.

Taris, T. W. and G. R. Semin. 1997. Passing on the faith: How mother-child communication influences transmission of moral values. Journal of Moral Education [online] 26 [cited 28.11. 2000]. Avaliable from: $<$ http://www.epnet.com/ehost/Finland/login.html $>$.

Valsiner, J. and G. Litvinovic. 1996. Processes of generalization in parental reasoning. In: Parents'cultural belief systems: their origins, expressions, and consequences, edited by S. Harkness and C. M. Super, pp. 56-82. New York: Guilford Press.

Woodward, K. 1997. Motherhood: identities, meanings and myths. In: Identity and difference, edited by K. Woodward, pp. 239-85. London: Sage.

Thurer, S, 1993. Changing conceptions of the good mother in psychoanalysis. Psychoanalytic Review 80(4):519-40. 


\section{Appendix}

\section{Characteristics of a good mother}

1. Loving, takes care, trustworthy, helping, never lets the child down, (Love).

2. Controls the child's behaviour, sets limits, discipline (Control).

3. Listens to the child, supports the child's growth into an independent person (Listens).

4. Makes no sacrifices, takes care also of herself.

5. Gives advice, teaches the child the importance of work and honesty (Advice).

6. Fair, just (Just).

7. Forgets her own interests in cases of conflict, serves others (Sacrifice)

8. Patient, understanding, has a sense of humour, not easily upset (Patience).

9. Consistent, purposeful (Consistence).

10. Supportive, trusts the child, helps the child to become confident (Support).

11. Honest to the child, apologizes also to the child (Honesty).

12. Acts as a model, uses herself as an example (Model).

13. Has time to spend with the child, in the child's hobbies, together with the child (Time).

14. Has a sense of responsibility (Responsible).

15. Takes the child's age, personality, skills into account.

16. Takes care of the religious upbringing of the child (Religion).

17. A good mother is a housewife (Housewife) 